\title{
Systematic Modeling Study on Guidance Strategy of College Foreign Language Teaching Development
}

\author{
Li Zong \\ School of Foreign Languages \\ East China Jiaotong University \\ Nanchang, China \\ rachel@163.com
}

\begin{abstract}
Aiming at the existing problems in the current college foreign language teaching the author put forward basic orientation and concept of reform and development of college foreign language teaching; with the application of systematic modeling macro frame model and new development guidance pattern are also proposed regarding to the systematic project-the study on guidance strategy of college foreign language teaching so that another new visual angle for China college foreign language teaching reform could be offered.
\end{abstract}

Keywords-component; college foreign language teaching: development guidance strategy: systematic modeling

\section{INTRODUCTION}

With the development of China's reform and opening policy, foreign language teaching in China has made breakthroughs and great progress, especially in English teaching reforms. In recent years, reforms in foreign language teaching have gained much attention from the whole society, which leads to higher development in teaching theories and strengthening of reforms. But along with permeating globalization in every aspect of society, the increasing global interaction in fields of economy, technology and culture bring about higher and diversified demands to quality of the talent, in the meanwhile stern challenges for foreign language teaching. [1,2] However, there are still long-rooted problems in college English teaching, as well as old and new issues[3,4](1)Educational thoughts and objectives are far too inadaptable to fast development of social needs (2)Educational models and means are rather lagging (3)existing educational evaluation system do not seem to connect with social demands (4)faculty trainings need be strengthened (5)editing of teaching materials has relatively time delay (6)teaching management systems are immature.

Aiming at the existing problems in the current college foreign language teaching, the thesis put forward basic orientation and concept of reform and development of college foreign language teaching; with the application of systematic modeling macro frame model and new development guidance pattern are also proposed regarding to the systematic project-the study on guidance strategy of college foreign language teaching so that another new visual angle for China college foreign language teaching reform could be offered.

\section{STRATEGIES OF REFORM AND DEVELOPMENT OF COLLEGE Foreign LANGUAGE TEACHING}

1) Transformation of Teaching Principles and Establishment of Education Orientation

Along with the rise of knowledge-driven economy in the 21st century, professional knowledge of foreign language talents has been supposed to be comprehensive and systematic; learning abilities should be dynamic and persistent. Hence, one of the tasks in university education is to teach students to "learn to learn" and educate forwardlooking, creative, inter-disciplinary and all-round talents. Teachers and administrators should reach a consensus to realize the transformation from educating linguistic and literary intelligence to all-round and comprehensive talents, which might widen training standard of higher education and satisfy social demand better.

A call for education for all-round development means that foreign language teaching should transform from pumping information to facilitating and steering students in knowledge and skills of various fiends. The tasks of teachers in college English education have been correspondingly changed, which results in inevitable changes in teaching models and means. In all-round development education Teacher-centered class teaching will be completely changed to students-centered learning which aims to develop autonomic learning abilities. Teachers should establish new teaching ideas centering on students' practice, and set up activity - centered teaching method to make full of subjective initiative through igniting potential desires of participation, widening horizon and developing creative thinking among students.

2) Reform Teaching Models and Refine Teaching Contents

Reforms of college English teaching lays emphasis on adoption of proper teaching models and means. The new, effective teaching models such as Scaffolding Instruction, Anchored Instruction and Random Access Instruction could be formed on the basis of group interaction theory and social constructivism theory. Those Interact Teaching Models all consist of four elements: students, teacher, teaching materials and teaching media, which are endowed with new connotations. Students are initiative knowledge producers, teachers are organizers and instructors, knowledge in teaching materials plays the role of reserve 
system for initiative producing of students and teaching media is supposed to work as a tool for creating teaching scene, cooperation and interaction, therefore with which teaching process could be more effective.

Certainly in addition to textbook teaching, combination of several methods like specialized training, lectures and network teaching platform should be applied to handle the process of teaching.

Autonomous learning cyclical model is an effective teaching model designed by Professor Zimmenman in the nineties of twentieth century, which consists of four interrelated components: self-evaluation and monitoring, installed aim and Strategic Planning, implementation and monitoring of strategies and monitoring of effects of strategies. The four components are interconnected and run in circles all through the autonomous learning process. Leaning means and adaptive ability are the key to success rate in learning, and autonomous learning cyclical model is one of teaching models which aims to develop adaptive abilities to improve learning. Therefore, it is a very effective teaching method and plays a vital role in the lifelong education age. Undoubtedly autonomous learning cyclical model has deserved a consensus and will be the focal point in educational reforms.

In addition, the new teaching model, which implements the theory of "combining language and content, integrate foreign language learning with disciplinary learning by using foreign language as teaching language which can motivate students to learn foreign language automatically and spontaneously during the process of pursuit in disciplinary learning."[5] This model has a very distinctive advantage.

\section{INTEGRATE MODERN INFORMATION TECHNIQUES AND ENRICH TEACHING METHODS}

The twenty-first century is information era during which multi-media teaching has been an important means in foreign language teaching with rapid rise of information and communication technology. The multimedia technique, which possesses the features of the movable images and that the picture and its accompanying text and sound are excellent, can provide ideal teaching environment for foreign language teaching. And it is the most effective teaching means to meet the needs of the education of the information society. Distance education is an effective way to overcome hurdles and obstacles such as shortage of teachers and classrooms and spread advanced teaching methods to remote regions through internet. Apparently, internet and multi-media technique are inevitable tools in modern foreign language teaching.

Multi-media technique has become the important vehicle of information in contemporary educational model, which disseminate information timely and efficiently as a vital channel of interaction of varieties of information when an interrelated and pluralistic constructive model of "teacher-multimedia-students" has been formed on the basis of various principles like teacher-students cooperation, optimization of teaching environment, learneroriented, and multi-dimensional information input.

With the aid of multi-media teaching model, educators guide and steer students, respond to feedback of students. In the meanwhile, students, who lead the subjective position in learning work the most of their potential and complete the meaning construction of knowledge in a co-operative way.

Teaching theories have been changing as modern information techniques develop. For example, on-line learning via e-mail, English learning websites, etc works as a bridge between teacher and students or among students. In a variety of foreign language study areas on Campus Network, including contents of classes, area of learning English for fun, and advice area for foreign language learning, educators can construct their own teaching system during teaching process of years, list teaching objective, contents, evaluation methods and teaching plans which can further constitute network resources reserve and work out specially adapted funny, interesting columns such as classic music, original movies and idiomatic English. Then a good communication can be built between teacher and students, leading to better partnership which depends on high frequency and effects of communication.

\section{ESTABLISH NEW MODEL FOR FACULTY TRAINING}

The key to reform of college foreign language teaching is to elevate faculty training, therefore establishment of a bran-new model for faculty training is vital and critical. Bilingual teaching demands educator should be qualified both in foreign language proficiency and other disciplinary basic knowledge and theories, which is quite challenging for teachers. Hence, there is a must for a transformation in faculty training that emphasizes language learning, subject learning and at the same time study of educational theories. Educators are required to broaden horizon out of book knowledge and spontaneously learn from advanced teaching methodology in other countries. For that reason, establishing the system of lifelong training for foreign language teachers is undoubtedly critical.

Modern computer-aided teaching techniques have been necessary skills for English teachers under the circumstance of contemporary education. A plenty of teaching courseware are based on those techniques like slide, projection, radio, TV and computer. Thus the design of multimedia courseware is practical process of learning modern advanced language teaching theories and methods.

\section{REFORM EVALUATION SYSTEM OF FOREIGN LANGUAGE TEACHING}

Reform of evaluation in foreign language teaching should uphold the people-oriented idea and try to fully demonstrate features of diversity, variety, comprehensiveness and development. Fine-grained evaluation of study could be taken as indicators of formative assessment in class learning, stage-dependent assessment reflecting units leaning and summative assessment at the end of semester.

The ultimate goal of foreign language learning is to communicate effectively by using foreign language, namely, communicative competence in extended aspect. What evaluation aims to do is cultivate development of communicative competence. Evaluation of leaning state and effect should be focused both on results and more importantly process of study. Accordingly, a new evaluation of students' learning should be established, changed from selection to cultivation. The principal task of 
designing class evaluation suitable for all-round education is to give priority to development instead of selection.

Comprehensive comment, which concerns individual variation should be the top concern of evaluation system, which focus on the combination of qualitative and quantitative evaluation, resulting in diversified patterns in place of merely grading; participation in interaction and combined self-evaluation and preceptor-evaluation; pluralistic subjects in evaluation, namely transfer from unitary to multi-variant ; change of evaluation contents from merely comments on scores to all-round development; change from stable process evaluation to dynamic process; change from assessment of the past and the present to the future of students.

\section{SyStematic Modeling OF GUIDANCE STRATEGy OF COLlEge Foreign LANGUAGE TEACHING DEVELOPMENT}

Reform and development of college foreign language teaching is a very complicated and systematic project. The author aims to explore construction of modules of guidance strategy of college foreign language teaching development. Based on analysis, the author proposed the system of development guidance on college foreign language teaching should consist of two modules: evaluation sub-module and development guidance submodule. The latter is employed to bring about development guidance strategies, make assessment though evaluation sub-module and modify evaluation system. The assessment of evaluation sub-module will work output feedback to the sub-module of development guidance, leading to decision-making. As Table 1

TABLE I. SYSTEMATIC STRUCTURE OF DEVELOPMENT GUIDANCE ON COLLEGE FOREIGN LANGUAGE TEACHING

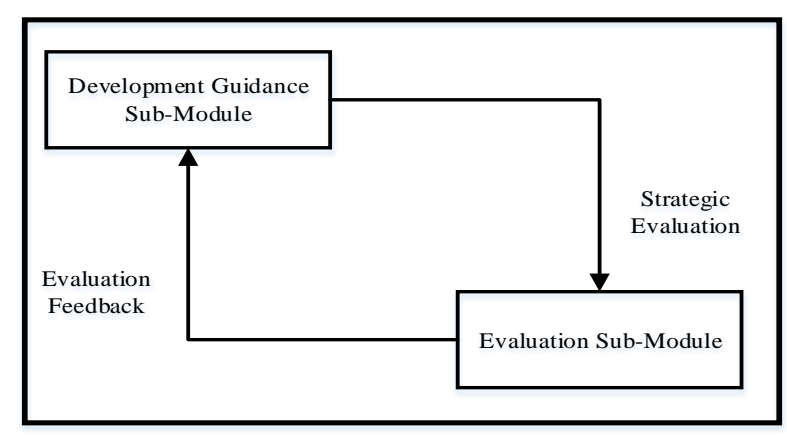

Evaluation sub-module mainly includes modules of evaluation input indicator detection, evaluation calculation implementation, evaluation strategies and theory foundation, database, knowledge base and way base, evaluation contents setting, evaluation indicators setting and comprehensive output of evaluation. As Table 2

The work process of evaluation sub-module can be described as: related indicators from practical teaching system are collected and saved through evaluation input indicators detection module, and then evaluation strategies module and evaluation contents setting module will work together to confirm strategies and contents of evaluation, on basis of which real statistics can be filtered and screened out. Next calculation results of indicators will be transferred to evaluation output module, and final overall evaluation results will be concluded on aggregate indicators in evaluation indicators module while feedback output will be delivered to development guidance system as indicators for decision of development guidance strategy setting. During the working process, evaluation strategies and theory foundation module, data base and way base always lead a role of guidance and support in choosing, calculating, and processing of evaluation indicators.

TABLE II. AgGRegate Mode of Evaluation Sub-Module

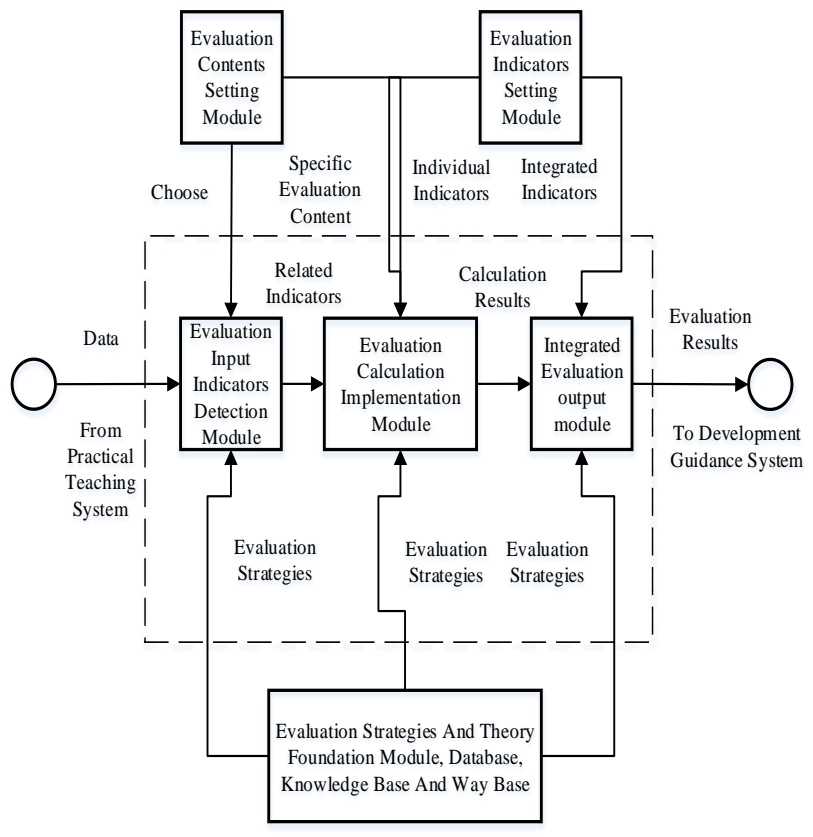

Aggregate model of development guidance sub-module covers evaluation input indicators transformation module, development guidance implementation module, aggregate guidance mode setting module, guidance strategies theory foundation module, database, knowledge base and way base, and guidance output modules, etc.

The work process of development guidance submodule can be described as: evaluation results from subsystem are processed through evaluation input indicator transformation module, transformed to related variable indicators for evaluation, and then go through unified reasoning on the support of aggregate guidance mode and theory of guidance strategies. The design of aggregate guidance mode mainly refer to teaching theories and teaching training mode, which is quite impacted and conditioned by social background, cultural and scientific background, political and resource situation. After the process, development guidance implementation module will import results of reasoning in guidance strategies into guidance result output module. Guidance strategies will be brought out through processing, integration and transformation, and then applied to operation, management and development of teaching systems, finally guidance of specific teaching practice. Teaching systems constitute the following aspects: teaching model, teaching content, teaching methods, faculty training mode, and teaching evaluation model, etc. Guidance strategies from the teaching systems will also be employed to revise the evaluation system, and be re-evaluated with evaluation system. 
TABLE III. AgGregate Mode of DeVElopment Guidance SubMODULE

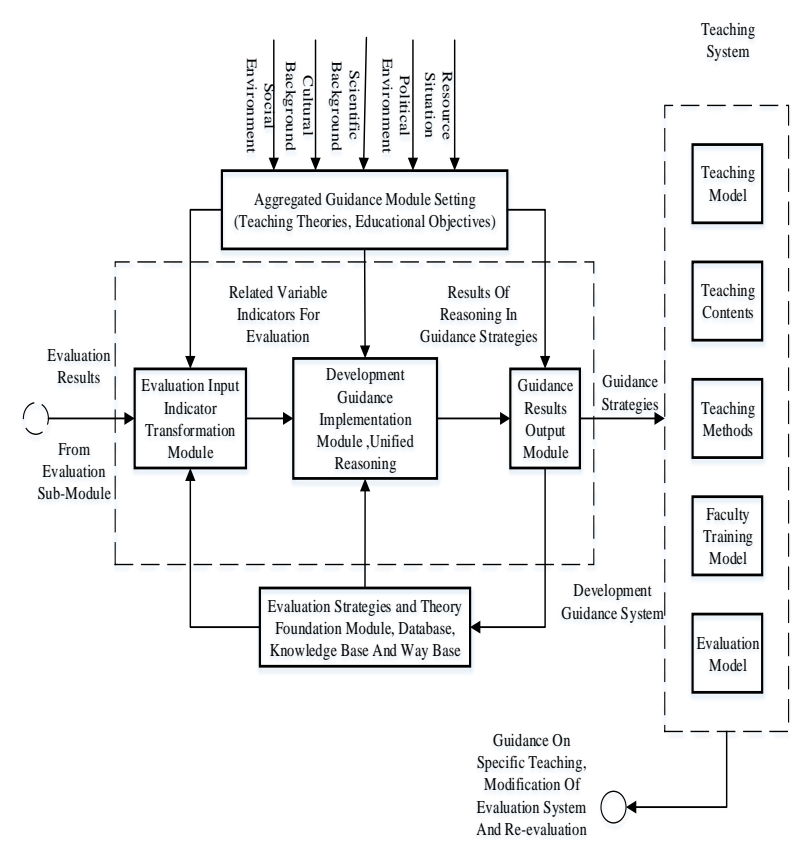

Development guidance mode for college foreign language teaching has come into a general frame on which a more effective organization and management of college foreign language teaching process with development strategies of college foreign language reform will be constructed. The thesis tries to propose a new study mode of development guidance in foreign language teaching, while specific guidance strategies, social practice and effect analysis will be further discussed.

\section{CONCLUSION}

Aiming at the existing problems in the current college foreign language teaching the thesis put forward basic orientation and concept of reform and development of college foreign language teaching; with the application of systematic modeling macro frame model and new development guidance pattern are also proposed regarding to the systematic project-the study on guidance strategy of college foreign language teaching so that another new visual angle for China college foreign language teaching reform could be offered.

\section{REFERENCES}

[1] College English Curriculum Requirements (for Trial Implementation), Shanghai Foreign Language Education Press, Shanghai , 2004

[2] H. Douglas Brown. 2001. Teaching by Principles: An interactive approach to language pedagogy[M]. Foreign language Teaching and Research Press

[3] William Littlewood. 2000. Foreign and Second Language learning[M].Cambridge University Press [

[4] Wong, P. Loh, C. S. 2000 Evaluating Computer-based Educational Resource, Integrating Technology into Teaching and learning[J]. National Institute of Education, US

[5] Cao Jing, Li Shihong, Liao Xiaoqun. Exploration Into Cognitive Learning Based on Computer-based educational game[J]. Journal of Guangxi University for Nationalities (Natural Science Edition), 2009, 2 (in Chinese)

[6] Wei Ting, Li Yi. Review of Educational Game Design at Home and Abroad[J]. Journal of Distance Education, 2009, 3(in Chinese)

[7] Scarcella, R. C., \& Oxford, R. L.1992. The tapestry of language learning: the individual in the communicative classroom. Boston,MA: Heinle \& Heinle.

[8] Vandergrift, L. 1997. The comprehension strategies of second language (French) listeners: A descriptive study. Foreign Language Annals, 30 (3) , 387-409.

[9] Nunan, D. 2002. Listening in language learning. In J.C. Richards \& W.A. Renandya ( Eds.), Methodology in language teaching: An anthology of current practice ( 238 -241). Cambridge,UK:

[10] Cowie, A. P. 1992. Multi-word lexical units and communicative language teaching. In P. Arnaud \& H. Bejoint. (Eds.). Vocabulary and Applied Linguistics. London: Macmillan.

[11] Ellis R. 2002. Understanding Second Language Acquisition. Shanghai: Shanghai Foreign Language Education Press.

[12] Hakuta, K. 1976. A Case Study of a Japanese Child Learning English as a Second Language. Language Learning (2): 321-51. 